\title{
Sequential extraction of different pools of phosphorus in alluvial and acid Soils of Uttarakhand
}

\author{
Pawan Kumar Pant*, Shri Ram and Aakash Mishra
}

Department of Soil Science, College of agriculture, G.B. Pant University of Agriculture and Technology, Pantnagar -263145 (Uttarakhand), INDIA

*Corresponding author. E-mail: pwnpant5@gmail.com

Received: March 13, 2016; Revised received: March 22, 2017; Accepted: October 18, 2017

\begin{abstract}
The sequencing and availability of inorganic and organic fractions of phosphorus at different days interval in two soils after the fertilizer (SSP) application was the objective of this investigation. The study helped to obtain the sequence of dominating pool of phosphorus at different days intervals and the rate of release in the soil. This sequential fractionation was used for two native soils i) Alluvial soil and ii) Acidic soil, with 0 to $80 \mathrm{ppm} \mathrm{SSP/100} \mathrm{gm}$ soil added in a pot experiment and the soil samples were analyzed at different days intervals started from 5 days to 60 days. The result revealed that amount of maximum total $P$ fell in the range from 325.14 to $387.30 \mathrm{mg} \mathrm{kg}^{-1}$ and 284.60 to $330.25 \mathrm{mg} \mathrm{kg}^{-1}$ for alluvial soil and acid soil, respectively up to 30 days. In case of inorganic $P$ fractions under alluvial soil the dominating species were like $\mathrm{Ca}-\mathrm{P}>\mathrm{Fe}-\mathrm{P}>\mathrm{Al}-\mathrm{P}>$ Saloid-P, while under acidic soil the following order Fe-P > Al-P > Ca-P > Saloid-P was observed. These two observations also drew the concentration of organic- $P$ fractions in soil. The work concluded that the availability of dominant phosphorus fraction up to 30 days received the maximum Ca-P concentration in alluvial soil and Fe-P up to 60 days in acidic soils, respectively.
\end{abstract}

Keywords: Al-P, Ca-P, Fe-P, Inorganic phosphate, Organic Phosphate, P-Fixation, Phosphorus pools

\section{INTRODUCTION}

Parent material and fertilization are the inputs in soil phosphorus cycle, and availability of this primary nutrient depends on amounts of labile forms. The continued application of fertilizer phosphorus $(\mathrm{P})$ is always required to maintain available pool of phosphorus in soil system, although most (>90\%) of the applied $\mathrm{P}$ remains in the soil as inorganic and organic $\mathrm{P}$ (Condron et al., 2005; Nash et al., 2014). Plants absorb phosphorus mainly in inorganic form and the major proportion of soil-P remains interlocked in various forms but not available for plant use. Soil P dynamics influence the role of the inorganic and organic phosphorus, as well as the fate of added phosphate fertilizer. This fate and bioavailability of fertilizer $\mathrm{P}$ in soil - plant systems has been widely studied using a variety of techniques, including sequential fractionation and ${ }^{31} \mathrm{P}$ nuclear magnetic resonance (NMR) spectroscopy (Cross and Schelinger, 1995; Turner et al., 2005; Negassa and Leinweber, 2009; Condron and Newman, 2011).

Manure contains a significant proportion of organic $\mathrm{P}$ fractions and inorganic $\mathrm{P}$ forms. In manure, organic $\mathrm{P}$ represents less than $30 \%$ of the total $\mathrm{P}$ content (Romanya and Rovira, 2009). In calcareous soils, $\mathrm{P}$ is mainly precipitated as Ca phosphates at higher concentration of orthophosphate in solution (Castro and Torrent, 1998. Tunesi et al.,1999). Soils of humid temper- ate and tropical regions are highly weathered, acidic and dominated by large quantity of sesquioxides. These soils easily adsorb and fix $\mathrm{P}$ in many cases leading to phosphorus limitations (Cross and Schlesinger, 1995). In such soils, the first products formed would be amorphous $\mathrm{Al}$ and Fe phosphates. Each of these reactions will result in very insoluble compounds of phosphate that are generally not available to plants.

Therefore, the knowledge of different $\mathrm{P}$ fractions and the most available form at different days interval after application of fertilizers is very important to understand in soil plant system. Although plants absorb phosphorus from the labile $\mathrm{P}$ pool consisting of resin$\mathrm{P}, \mathrm{NaHCO}_{3}$-Pi and $\mathrm{NaHCO}_{3}$-Po fractions in soil, but other $\mathrm{P}$ fractions like dilute $\mathrm{H}_{2} \mathrm{SO}_{4}$ extractable $\mathrm{P}$, also contribute variably to plant-available $\mathrm{P}$ (Gichangi et $a l ., 2009)$. In this investigation, a sequential extraction procedure have been followed at different days intervals to characterize dominating form of phosphorus by determining the amount of inorganic $\mathrm{P}$ and organic $\mathrm{P}$ extracted by different reagents in alluvial and acid soils of Uttarakhand.

\section{MATERIALS AND METHODS}

The soils of U.S. Nagar and Nainital district were selected for the present investigation. The U. S. Nagar is located in northern part of India at $29^{\circ} 00.767^{\prime} \mathrm{N}$ latitude and $79^{\circ} 29.279^{\prime} \mathrm{E}$ longitude while Nainital located 
at $29^{0} 33.075^{\prime} \mathrm{N}$ latitude and $79^{0} 36.555^{\prime} \mathrm{E}$ longitude. The U. S. Nagar soils are majorly considered as a Tarai soil (foot hill soils) where, had major deposition of alluvium material with partial kankary soils whereas, Nainital soils belonged to the hill soils and was slight to moderate acidic in reaction. The soil samples for alluvium soil treatment were collected at from the agricultural field of Crop Research Centre (CRC), Pantnagar, U. S. Nagar and for acid soils, samples collected from the Kwarab village of Nainital district from 0-15 $\mathrm{cm}$ of depth. The collected samples were brought to the soil science laboratory, Pantnagar and analyzed for the various chemical properties by using standard methodology. The pot experiment conducted in complete block design (CRD) consisted 8 treatments $T_{1}$ : (control), $\mathrm{T}_{2}: 5$ ppm SSP, $\mathrm{T}_{3}: 10 \mathrm{ppm} \mathrm{SSP}, \mathrm{T}_{4}: 20 \mathrm{ppm}$ SSP, $\mathrm{T}_{5}: 30 \mathrm{ppm} \mathrm{SSP,} \mathrm{T}_{6}: 40 \mathrm{ppm} \mathrm{SSP,} \mathrm{T}_{7}: 60 \mathrm{ppm}$ SSP and $\mathrm{T}_{8}: 80 \mathrm{ppm}$ SSP, was replicated three times. The sequential fractionation was used for these two native soils was maintained with 0 to 80 ppm SSP solution for per $100 \mathrm{gm}$ of soil then as per requirement the moisture level was maintained in pots by using distilled water to keep the moisture level at $80 \%$ field capacity. These samples were then analyzed at different days interval started from 5 days to 60 days.

Different $\mathrm{P}$ fractions in soil were determined with the method suggested by Peterson and Corey (1966). Each of $\mathrm{P}$ fractions was extracted from the soil by treating it with different extractant i.e. Saloid-P by $1 \mathrm{~N} \mathrm{NH}_{4} \mathrm{Cl}$, Al-P by $0.5 \mathrm{M} \mathrm{NH}_{4} \mathrm{~F}$, Fe-P by O.1N NaOH, Ca-P by $0.25 \mathrm{M} \mathrm{H}_{2} \mathrm{SO}_{4}$ and measured on the spectornic 20 at the specified wavelength. The organic $\mathrm{P}$ was determined by the method suggested by Bowman and Cole (1978). The laboratory and experimental data were analyzed by using standard statistical procedure (Snedecor and Cochran, (1967).

\section{RESULTS AND DISCUSSION}

The chemical analysis of collected samples presented in Table 1 recorded the soil reaction of the samples fell under neutral to slight alkaline in reaction under alluvial soil to slight acidic under acidic soil samples, respectively. The texture of the sample was silty clay loam and sandy loam for alluvial and acidic soil, respectively. These both parameters (soil reaction) are the most influential factor for the release or adsorption/ precipitation of $\mathrm{P}$ in any soil.

Influence of carbon: Phosphorus ratio: The $\mathrm{C}$ to $\mathrm{P}$ ratio is a prime controlling factor to avail $\mathrm{P}$ in any soil. One reason of decreasing the availability of $\mathrm{P}$ with increasing $\mathrm{C}: \mathrm{P}$ ratio is due to stimulation of soil microbial biomass. Microbes break down organic matter and utilize nutrients such as nitrogen and $\mathrm{P}$ for their growth, thereby immobilizing (tying up) these nutrients in their biomass (Leytem et al., 2005). Another study showed that when cattle manure and $\mathrm{P}$ fertilizers were applied together, the recovery of $\mathrm{P}$ was greater than when fertilizer $\mathrm{P}$ was applied alone, most likely due to added C (Halajnia et al., 2009). Likewise, in present investigation, it seemed from the table 1 that the organic carbon percent was higher in alluvial soil as compared to acid soil samples which laid more total $\mathrm{P}$ to get accounted in alluvial soil than that of acid soil. Phosphorus fractionation: The different $\mathrm{P}$ fractions of alluvial soil and acidic soil in incubation study were varies at different days interval. The amount sequenced for these fractions from 5 days after incubation (DAI) to 60 days after incubation (DAI) are given below in incubation study.

Total phosphorus (mg $\left.\mathbf{k g}^{-\mathbf{1}}\right)$ : The both locality soil samples had varied concentration of total $\mathrm{P}$ ranging from 325.14 to $387.30 \mathrm{mg} \mathrm{P} \mathrm{kg}^{-1}$ soil in alluvial soil and 284.6 to $330.25 \mathrm{mg} \mathrm{P} \mathrm{kg}^{-1}$ soil in acidic soil to up to 30 days after incubation. There was consistent increase in total $\mathrm{P}$ up to 30 days after incubation and then recorded declining trend of $\mathrm{P}$ in later days (Table 2). The higher total $P$ content may be due to higher oxides of iron and organic carbon content which are effective immobilizers of $\mathrm{P}$ (Kalaivanan and Sudhir 2012). The both region samples recorded significantly lowest and highest total phosphorus concentration in $\mathrm{T}_{1}$ and $\mathrm{T} 8$ treatment, progressively up to 30 days after incubation, respectively.

Saloid phosphorus $\left(\mathbf{m g ~ k g}^{-1}\right)$ : The Saloid fraction of $\mathrm{P}$ was extracted by using ammonium chloride extraction solution which brought the $\mathrm{P}$ to be in range from 1.23 to $20.45 \mathrm{mg} \mathrm{kg}^{-1}$ and 0.49 to $3.89 \mathrm{mg} \mathrm{kg}^{-1}$ in alluvial and acid soils, respectively, which increased consistently up to 30 days after incubation (DAS) and then decreased eventually up to 60 days after incubation (DAI) (Fig. 1). The trend of overall findings followed the order of total phosphorus extraction. However, there was appreciable increment of saloid-P in alluvial soil than that of acid soil samples. The relatively higher content of Saloid-P in case of Alluvial soil could be attributed to the transformation of applied $\mathrm{P}$

Table 1. Physico-chemical properties of two native soil samples of Uttarakhand.

\begin{tabular}{llll}
\hline S.N. & Property & Alluvial Soil & Acidic Soil \\
\hline $\mathbf{1 .}$ & pH $(1: 2.5$ soil: water suspension $)$ & 7.48 & 5.53 \\
$\mathbf{2 .}$ & EC $\left(\mathrm{ds} \mathrm{m}^{-1}\right)$ & 0.32 & 0.14 \\
$\mathbf{3 .}$ & Organic carbon $(\%)$ & 0.79 & 0.55 \\
$\mathbf{4 .}$ & Available N $\left(\mathrm{kg} \mathrm{ha}^{-1}\right)$ & 200.70 & 160.07 \\
$\mathbf{5 .}$ & Available P $\left(\mathrm{kg} \mathrm{ha}^{-1}\right)$ & 14.12 & 7.79 \\
$\mathbf{6 .}$ & Available K $\left(\mathrm{kg} \mathrm{ha}^{-1}\right)$ & 137.76 & 152.32 \\
$\mathbf{7 .}$ & Moisture content $(\%)$ & 11.23 & 6.08 \\
\hline
\end{tabular}


Pawan Kumar Pant et al. / J. Appl. \& Nat. Sci. 9 (4): 2280 - 2284 (2017)

Table 2. Total- $\mathrm{P}\left(\mathrm{mg} \mathrm{kg}^{-1}\right)$ concentration in alluvial and acid soil of Uttarakhand at different days interval.

\begin{tabular}{|c|c|c|c|c|c|c|c|c|c|c|c|c|}
\hline \multirow[b]{3}{*}{ Treatments } & \multicolumn{12}{|c|}{ Total -P (mg kg-1) } \\
\hline & \multicolumn{2}{|c|}{5 Days } & \multicolumn{2}{|c|}{10 Days } & \multicolumn{2}{|c|}{15 Days } & \multicolumn{2}{|c|}{ 30 Days } & \multicolumn{2}{|c|}{ 40 Days } & \multicolumn{2}{|c|}{60 Days } \\
\hline & $\begin{array}{l}\text { Allu- } \\
\text { vial } \\
\text { Soil } \\
\end{array}$ & $\begin{array}{c}\text { Acid } \\
\text { Soil }\end{array}$ & $\begin{array}{c}\text { Allu- } \\
\text { vial } \\
\text { Soil }\end{array}$ & $\begin{array}{c}\text { Acid } \\
\text { Soil }\end{array}$ & $\begin{array}{c}\text { Allu- } \\
\text { vial } \\
\text { Soil }\end{array}$ & $\begin{array}{l}\text { Acid } \\
\text { Soil }\end{array}$ & $\begin{array}{c}\text { Allu- } \\
\text { vial } \\
\text { Soil }\end{array}$ & $\begin{array}{c}\text { Acid } \\
\text { Soil }\end{array}$ & $\begin{array}{c}\text { Allu- } \\
\text { vial } \\
\text { Soil }\end{array}$ & $\begin{array}{c}\text { Acid } \\
\text { Soil }\end{array}$ & $\begin{array}{c}\text { Allu- } \\
\text { vial } \\
\text { Soil }\end{array}$ & $\begin{array}{c}\text { Acid } \\
\text { Soil }\end{array}$ \\
\hline T1 & 325.14 & 284.60 & 325.39 & 284.93 & 325.72 & 285.79 & 326.54 & 286.42 & 325.81 & 285.75 & 325.11 & 284.86 \\
\hline T2 & 328.27 & 296.68 & 328.76 & 297.12 & 337.52 & 298.00 & 340.49 & 299.38 & 337.53 & 297.99 & 333.82 & 296.52 \\
\hline T3 & 329.72 & 304.90 & 330.21 & 305.24 & 339.36 & 305.78 & 345.31 & 307.52 & 342.39 & 306.28 & 340.23 & 304.53 \\
\hline T4 & 330.76 & 309.55 & 331.66 & 310.02 & 343.66 & 312.27 & 348.62 & 314.73 & 347.48 & 313.29 & 344.45 & 311.25 \\
\hline T5 & 332.68 & 312.79 & 333.23 & 313.20 & 348.60 & 315.70 & 353.61 & 317.88 & 351.03 & 315.48 & 347.66 & 313.74 \\
\hline T6 & 335.62 & 315.58 & 335.72 & 316.18 & 357.73 & 318.77 & 364.52 & 320.69 & 364.20 & 318.25 & 360.61 & 316.72 \\
\hline T7 & 338.43 & 317.97 & 338.83 & 318.78 & 365.49 & 321.38 & 371.45 & 324.61 & 373.41 & 322.06 & 370.01 & 319.92 \\
\hline T8 & 344.66 & 323.29 & 345.17 & 324.03 & 379.42 & 326.81 & 387.30 & 330.25 & 382.75 & 326.89 & 378.05 & 323.94 \\
\hline SEm \pm & 0.22 & 0.84 & 0.23 & 0.90 & 0.14 & 0.88 & 0.20 & 0.66 & 1.00 & 0.59 & 0.85 & 0.63 \\
\hline $\begin{array}{l}C \\
(P=0.05)\end{array}$ & 0.66 & 2.51 & 0.68 & 2.70 & 0.42 & 2.63 & 0.59 & 1.99 & 3.01 & 1.78 & 2.54 & 1.90 \\
\hline
\end{tabular}

into Saloid-P. The results are in agreement with Jatav et al. (2010).

Aluminium bound phosphorus $\left(\mathrm{mg} \mathrm{kg}^{-1}\right)$ : This form of $P$ fraction fell in range from 9.76 to $28.28 \mathrm{mg} \mathrm{kg}^{-1}$ in alluvial soil and increased consistently up to 30 days after incubation (DAI) whereas, the concentration of the same in acid soils was from 18.03 to $43.37 \mathrm{mg} \mathrm{kg}^{-1}$ and increased consistently up to 60 days after incubation (DAI) (Fig. 2). However, the level of significance among the treatments was different at different days interval. Jackson (1957) suggested that $\mathrm{FePO}_{4}$ and $\mathrm{AlPO}_{4}$ would be found at lower $\mathrm{pH}$ and they may be

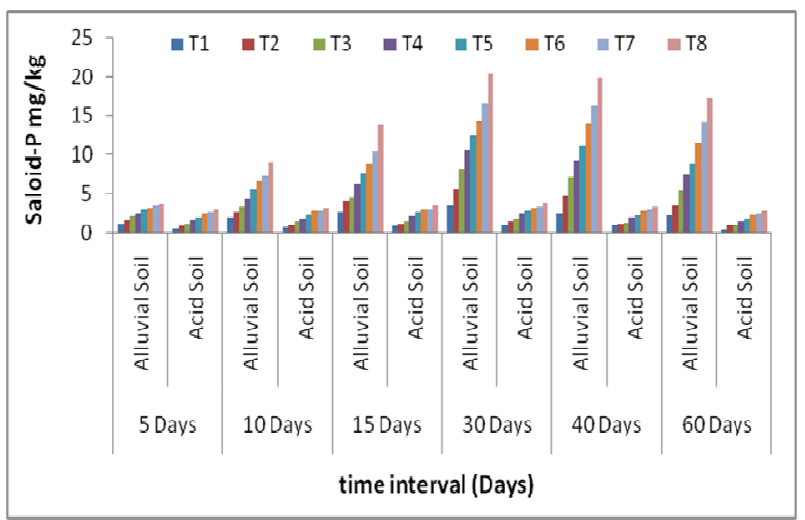

Fig. 1. Treatment wise distribution of Saloid-P in alluvial and acid soils at different days interval

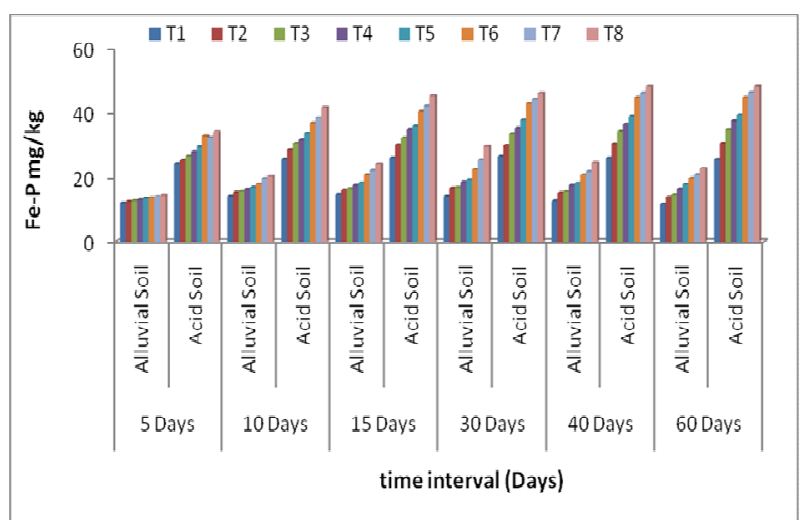

Fig. 3. Treatment wise distribution of Fe-P in alluvial and acid soil at different days interval. even from at $\mathrm{pH}$ above 7.0. However, they are relatively more stable at lower $\mathrm{pH}$. Thus, the study also reported the solubility of Al-P along with Fe-P more in acidic soil samples rather than of alluvium samples. However, the Al-P extracted by using $0.5 \mathrm{M} \mathrm{NH}_{4} \mathrm{~F}$ extractant reported less in concentration of $\mathrm{P}$ than that of Fe-P.

Iron bound phosphorus (Fe-P): The Fe-P concentration fell in the range from 12.03 to $29.56 \mathrm{mg} \mathrm{kg}^{-1}$ in alluvial soil and increased consistently up to 30 days after incubation (DAI) whereas, the concentration of the same in acid soils was from 24.12 to $48.23 \mathrm{mg} \mathrm{kg}^{-}$

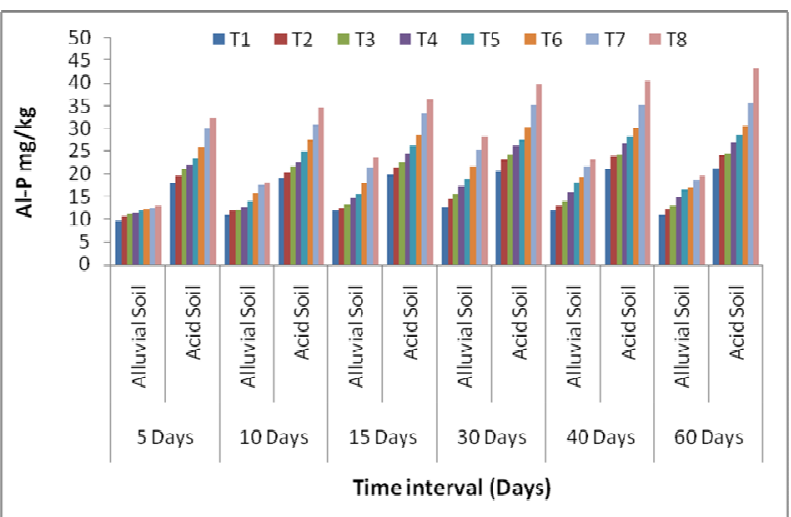

Fig. 2. Treatment wise distribution of Al-P in alluvial and acid soils at different days interval.

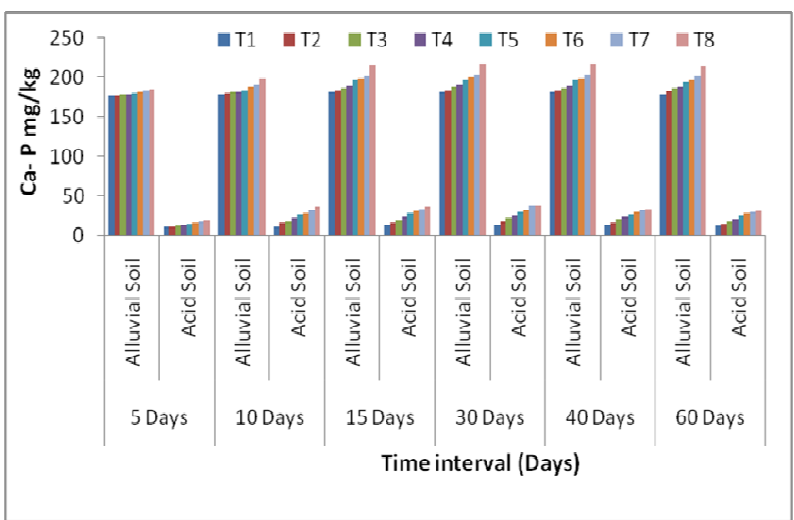

Fig. 4. Treatment wise distribution of $\mathrm{Ca}-\mathrm{P}$ in alluvial and acid soils at different days interval. 


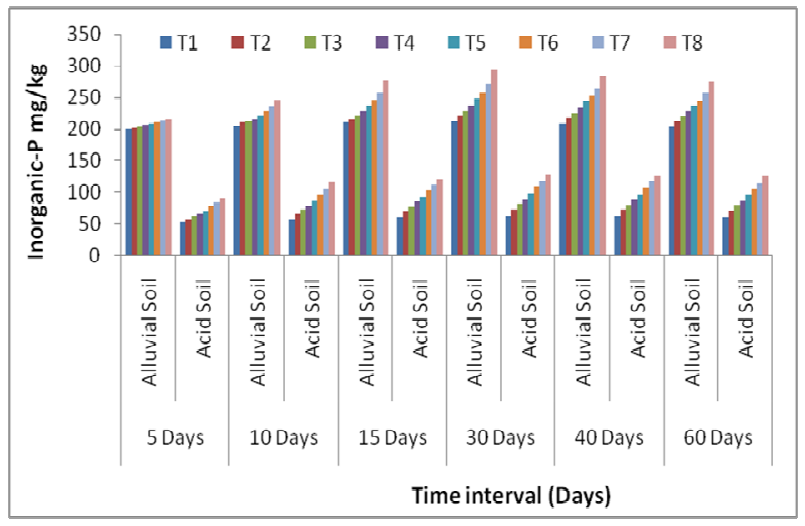

Fig. 5. Distribution of inorganic- $P$ in alluvial and acid soil samples at different days interval.

${ }^{1}$ and increased consistently up to 60 days after incubation (DAI) (Fig. 3). This replenishment of phosphorus as Fe-bound phosphorus was more in the samples collected from the hills of Nainital (acidic soil) than that from the samples collected for alluvial soil. This variation of $\mathrm{P}$ concentration was due to low $\mathrm{pH}$, high percentage of free sesquioxides and intense weathering which laid more replenishment of $\mathrm{P}$ in acidic soils than alluvial soil. Also at later days, a major portion of these two reductant soluble-P and occluded-P might have converted into ferrous phosphate giving consistently higher values as Fe-P. In addition to these processes, Among the $\mathrm{P}$ sources, SSP resulted in the formation of more Fe-P during different periods of incubations in the soil as the soluble (Singh and Singh, 1976).

Calcium bound phosphorus (Ca-P): The $\mathrm{pH}$ of alluvial soil samples ranged to slight alkaline in reaction recorded the highest concentration of $\mathrm{Ca}-\mathrm{P}$ than that in acid soil samples which was then solubilised by using extracting solution of $0.25 \mathrm{M} \mathrm{H}_{2} \mathrm{SO}_{4}$ for its determination. At this range, the calcium reacts with $\mathrm{P}$ to form calcium phosphate $\left(\mathrm{CaPO}_{4}\right)$ precipitates accounted more of Ca-P in alluvial soil samples. This form of $\mathrm{P}$ in alluvial soil samples fell in range from 176.68 to $216.77 \mathrm{mg} \mathrm{kg}^{-1}$ to 11.14 to $37.90 \mathrm{mg} \mathrm{kg}^{-1}$ in acid soil samples, respectively (Fig. 4). However, after each increment of $\mathrm{P}$ solution in treatments recorded highest $\mathrm{Ca}-\mathrm{P}$ to get accounted up to 30 days after incubation (DAI) consistently than there was decreasing trend of attaining $\mathrm{Ca}-\mathrm{P}$ at later days in both site samples. This may be due to the gradual dissolution of Ca-P from $\mathrm{P}$ fertilizers. The low content of Ca-P in the acid soil may be due to low $\mathrm{pH}$ and low calcium carbonate content (Negassa and Leinweber, 2009).Similar findings were also reported in Vertisols of Maharashtra by $\mathrm{Pu}-$ ranik et al. (1979) who suggested that the presence of $\mathrm{Ca}-\mathrm{P}, \mathrm{Al}-\mathrm{P}$ and Occl-P fractions in soils was related to stages of weathering and their differential solubilities.

Proportionate distribution of inorganic $P$ fractions over organic $P$ fraction $\left(\mathrm{mg} \mathrm{kg}^{-1}\right)$ : The proportionate distribution of organic $\mathrm{P}$ by deducting from total $\mathrm{P}$ was

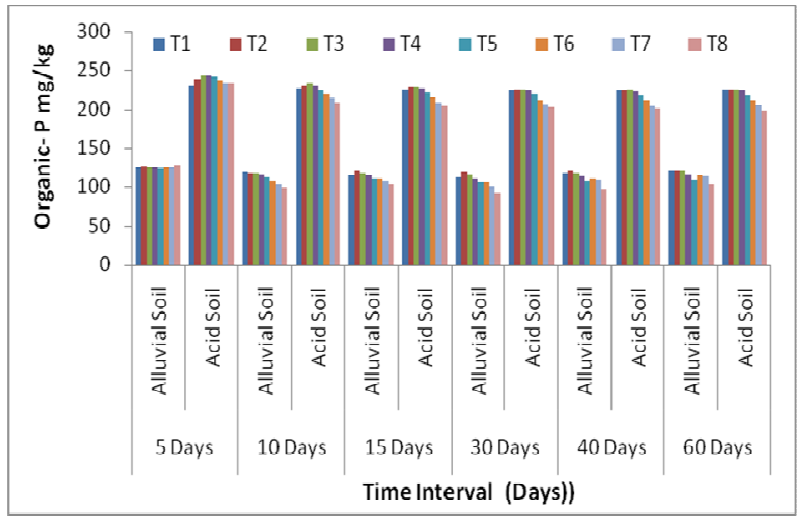

Fig. 6. Distribution of organic-P in alluvial and acid soil samples at different days interval.

calculated in both native soils. This part signified the concentration of inorganic $\mathrm{P}$ in alluvial soil was more in amount in comparison to acid soil samples where organic $\mathrm{P}$ was in appreciable amount (Figs. 5 and 6). Out of all fractions the Ca-P was predominant species in alluvial soil, followed by Fe-P and Al-P, while in acid soil samples Fe-P was dominated species followed by Al-P and Ca-P. Bhatia and Hari Shankar (1982) reported that inorganic $\mathrm{P}$ was major portion $(91.25 \%)$ out of total $\mathrm{P}$ in alluvial soils of U.P. and further concluded that $\mathrm{Ca}-\mathrm{P}$ was predominant form followed by $\mathrm{Fe}-\mathrm{P}$ and Al-P.

\section{Conclusion}

Various solubilizing agent were used to fractionize the dominating $\mathrm{P}$ species in two native soils of Uttarakhand and it is concluded that days interval are the key factor which determine the availability of different phosphorus fraction in different soil. The observation resulted that out of inorganic fractions, the availability of ca- phosphate $\left(216.90 \mathrm{mg} \mathrm{kg}{ }^{-1}\right)$ up to 30 days is more in alluvial soil, whereas, availability of Fe-P and Al-P (48.23 and $43.37 \mathrm{mg} \mathrm{kg}^{-1}$ ) is more in acidic soil even up to 60 days. The overall fraction of organic- $\mathrm{P}$ is more during initial days which got reduced during 30 days interval and remained consistent up to 60 days interval. Therefore, the days interval in the release of different fractions of phosphorus proved to be significant factor. Also, the kind of fertilizer application is one of the deciding factor that decides the rate of solubility in soil. At the last, the relative abundance of inorganic $\mathrm{P}$ species followed the order $\mathrm{Ca}-\mathrm{P}>\mathrm{Fe}-\mathrm{P}>\mathrm{Al}-\mathrm{P}$ $>$ Saloid-P in alluvial soil while acid soil samples were sequenced as Fe-P > Al-P > Ca-P > Saloid-P.

\section{REFERENCES}

Bhatia, K.S. and Hari Shankar. (1982). Distribution of phosphorus in soils of the central alluvial tract of Uttar Pradesh. J. Indian Soc. Soil Sci.30:542-544

Bowman, R.A., and C.V. Cole. 1978. An exploratory method for fractionation of organic phosphorus from grassland soils. Soil Sci. 125:95-101 
Castro, B., Torrent, J. (1998). Phosphate sorption by calcareous Vertisols and Inceptisols as evaluated from extended P- sorption curves. Eur. J. Soil Scie. 49: 661- 667.

Condron, L. M, Turner, B.L., Cade-Menun, B.J. (2005). Chemistry and dynamics of soil organic phosphorus. In: Sims, J.T., Sharpley, A.N. (Eds.), Phosphorus: agriculture and the environment. ASA/CSSA/SSSA, Madison, Wisconsin. United States of America, pp 87-121.

Condron, L. M., Newman, S. (2011). Revisiting the fundamentals of phosphorus fractionation in soils and sediments. J. Soils Sediments. 11: 830-840.

Cross, A., Schlesinger, W. (1995). A literature review and evaluation of the Headley fractionation: Applications to the biogeochemical cycle of soil phosphorus in natural ecosystems. Geoderma, 64: 197-214.

Gichangi, E.M., Mnkeni, P.N.S. and Brooks, P.C. (2009). Effects of goat manure and inorganic phosphate addition on soil inorganic and microbial biomass phosphorus fractions under laboratory incubation conditions. Soil Sci. Plant Nutr. 55: 764-771.

Halajnia, A., G. H. Haghnia, A. Fotovat and R. Khorasani. (2009). Phosphorus Fractions in Calcareous Soils Amended with $\mathrm{P}$ Fertilizer and Cattle Manure. Geoderma. 150: 209-213.

Jackson, M.L. (1957). Soil chemical analysis. Prentice-Hall Inc. Englewood Cliffs.N.J. pp.180-192.

Jatav, M.K., Sud, K.C. and Trehan, S.P. (2010). Effect of organic and inorganic source of phosphorus and potassium on their different fraction under potato- radish cropping sequence in brown hill soil. J. Indian Soc. Soil Sci.,58: 388-393.

Kalaivanan, D. and Sudhir, K. (2012) Phosphorus fractions of selected banana growing soils of India and their relationships with soil characteristics. Mysore J. Agric. Sci.,
46(1): 73-79.

Leytem, A. B., B. L. Turner, V. Raboy, and K. L. Peterson. (2005). Linking Manure Properties to Phosphorus Solubility in Calcareous Soils: Importance of the Manure Carbon in Phosphorus Ratio. Soil Sci. America J., 69: 1516-1524.

Nash, D., Haygarth, P., Turner, B., Condron, L., Mc-Dowell, R, Richardson, A., Watkins, M, Heaven, M. (2014). Using organic phosphorus to sustain pasture productivity: A perspective. Geoderma, 221-222, 11-19.

Negassa, W. and Leinweber, P. (2009) How does the Hedley sequential phosphorus fractionation reflect impacts of land use and management on soil phosphorus: A review. J. Pl Nutr. Soil Sci., 72: 305-325

Peterson, G.W. and R.B. Corey. (1966). A modified Chang and Jackson procedure for routine fractionation of inorganic soil phosphates. Soil Sci. Soc. Amer. Proc., 30:563- 565.

Puranik, R.B., Barde, N.R. And Ballal, D.K. (1979). Soil phosphorus as an index of weathering. Bulletin of the Indian Soc. Soil Sci. 12 :224-232.

Romanya, J., Rovira, P. (2009). Organic and inorganic P reserves in rain-fed and irrigated calcareous soils under long term organic and conventional agriculture. $\mathrm{Ge}$ oderma, 151: 378-386.

Singh, S. And Singh, S. B. (1976). Effect of water logging and organic matter in inorganic $\mathrm{P}$ fractions of soils. $J$. Indian Soc. Soil Sci.24 (1): 88-90.

Snedecor, G.W. and Cochran, W.G. (1967). Statistical methods $5^{\text {th }}$ ed. Oxford and IBH. Pub. Co. Eton Press, Calcutta.

Tunesi, S., Poggi, V., Gessa, C. (1999). Phosphate adsorption and precipitation in calcareous soils: the role of calcium ions in solution and carbonate minerals. Nutr. Cycle. Agroecosys. 53: 219-227. 